\title{
HAJI DALAM REFLEKSI
}

\author{
SYAIFUL RAHMAT PANGGABEAN
}

"Mengerjakan haji adalah kewajiban manusia terhadap Allah, yaitu orang-orang yang sanggup melaksanakan perjalanan ke Baitullah." (QS. 3: 97) ${ }^{1}$

\section{Pendahuluan}

Haji sebagai rukun Islam yang ke-5 yang disyariatkan oleh Allah kepada hamba-Nya. Ibadah ini penuh dengan hikmah dan ibrah bagi hidup dan kehidupan manusia di dunia. Satu di antaranya adalah kesamaan manusia di hadapan Tuhannya tanpa diskriminasi antara siapa yang pemimpin dan siapa yang dipimpin, antara siapa yang kaya dan siapa yang miskin. Perbedaan hanya seberapa besar ketakwaan kepada-Nya (QS.49:13). ${ }^{2}$

Di sisi lain ibadah haji adalah proses seorang manusia untuk mencapai manusia sejati sebagai pelampiasan dua potensi yang diberikan Allah kepadanya.yaitu potensi sebagai hamba di hadapan Allah (QS. 51: 56) namun di sisi lain ia juga mempunyai potensi sebagai pemimpin $(k h a l i f a h)^{4} \mathrm{di}$

$$
\text { وله على الناس حج البيت من استطاع إليه سبيلا }
$$

Sesungguhnya orang yang paling mulia di antara kamu di sisi Allah ialah orang yang paling bertakwa diantara kamu".

"Dan tidak Ku-ciptakan jin dan manusia kecuali untuk menyembahKu”

Secara etimologi khalifah adalah من يخلفك ويقوم مقامك yakni orang yang datang setelah kamu dan menempati posisimu (Hijazy: 30). Dapat dinyatakan bahwa khalifah adalah seseorang yang dijadikan pengganti dari orang lain atau seseorang yang diberi wewenang duntuk bertindak dan berbuat sesuai dengan ketentuan-ketentuan yang memberi wewenang,. Hamka membagi pengertian khalifah kepada empat bagian, yakni, khalifah sebagai pengganti Rasul dalam urusan pemerintahan, khalifah sebagai pengganti atau alat dari Allah buat melaksanakan hukum Tuhan dalam pemerintahan-Nya atau ia sebagai pengganti nabi dan rasul sebelumnya, khalifah sebagai cucu umat manusia (Q.S.10:14), dan 
muka bumi (QS. 10: 14). ${ }^{5}$ Kedua potensi ini merupakan tujuan dari penciptaan manusia.

Kedua potensi tersebut tampak ketika seorang muslim mampu melaksanakan ibadah haji sebagai langkah terakhir menuju insan kamil (manusia sejati) $^{6}$ yang mampu mengemban dua potensi yang saling bertentangan hamba sekaligus pemimpin.

Kepemimpinan seorang muslim yang melaksanakan haji paling tidak tergambar dalam mengatur sisi materi atau mengatur keuangan sehingga ia mampu melaksanakan ibadah tersebut dan kepemimpinan atas nafsu yang ada dalam diri untuk tidak menghamburkan harta di jalan yang salah. Di sisi lain juga ia sebagai pemimpin harus menjamin kesejahteraan hidup orang yang dipimpinnya (keluarga) selama pergi meninggalkan mereka. Masih banyak lagi sifat-sifat kepemimpinan yang tersirat sebelum melaksanakan ibadah ini.

\section{Haji Penguat Iman Penyempurna Islam}

Ibadah haji sebagai rukun Islam, maka ia wajib bagi seorang muslim lagi yang beriman. Karena masih banyak manusia yang mampu mempercayai rukum iman yang enam namun tidak termasuk orang muslim dan begitu juga sebaliknya. Hal ini disebabkab menuju keislaman yang murni dan dibarengi dengan landasan iman bukanlah suatu hal yang mudah dibutuhkan katakwaan yang sebenarnya. Ini tercermin dalam al-Quran : "Hai

khalifah sebagai seluruh umat manusia (Q.S. 27:62) (Hamka: 159). Dengan demikian tugas khalifah untuk mengatur segala sesuatu di bumi dan menegakkan kebenaran dan keadilan memerlukan ilmu pengetahuandan daya fikir dan skill yang bagus.

$$
\text { .. ثم جعلنا خلائف في الأرض "Kemudian kami jadikan kamu khalaif 'pengganti-pengganti' }
$$

(mereka) di muka bumi”

${ }^{6}$ Menurut penulis kesempurnaan hidup manusia akan tercapai jika ia mampu menempatkan potensi yang ada pada dirinya, kapan sebagai hamba kepada Allah (hal-hal ukhrawi) dan kapan sebagai khalifah-Nya atau sebagai pemimpin (hal-hal dunyawy). Dan ini sering terdengar dalam doa "sapu jagat", "ربنا آنا في حسنة وفي الآخرة حسنة وقنا عذاب النار ( 
orang-orang yang beriman bertakwalah kamu kepada Allah sebenar-benar takwa dan janganlah kamu meninggal sebelum dalam keadaan muslim". (QS.3: 102). ${ }^{7}$

Untuk itu, kata istitha'ah (kemampuan) untuk melaksanakan ibadah haji janganlah selalu terfokus pada kemampuan materi tapi juga kemampuan spirit. Ibadah haji tanpa landasan keimanan sia-sia tanpa landasan keislaman adalah kebohongan belaka di mana ibadah ini merupakan aplikasi dari rukun yang sebelumnya, syahadat, salat, zakat, dan puasa dalam versi yang lebih besar. Zakat hanya mengeluarkan harta sedikit, untuk melakukan ibadah haji membutuhkan lebih banyak lagi, puasa menahan nafsu dan lapar (bersifat jasmani), haji lebih dari pada itu dibutuhkan ketahanan jasmani maupun rohani yang esktra, dan begitu juga dengan rukun-rukun yang lain.

Dengan kata lain, dapat dikatakan dengan melaksanakan ibadah ini keimanan seseorang tidak dapat diragukan lagi dan aplikasi atas rukun islam yang lain selain haji tidak dapat disangkal lagi. Dengan kedua syarat immateri ini untuk mencapai haji mabrur tidaklah susah bukan haji yang ngabur atau ngawur. Untuk itu pantas dinyatakan tiada balasan yang layak bagi haji yang mambrur selain surga.

Dengan modal immateri "2 rukun" dalam menunaikan ibadah haji kesempuranaan islam akan tercapai dan keimanan akan bertambah kuat dengan meyaksikan betapa Maha Besar dan Maha Kuasanya Allah dengan segala ciptaan-Nya yang selama ini belum dirasakan. Dengan perasaan yang kagum dan sadar bahwa ia sebagai hamba tidak ada apa-apanya di hadapan penciptanya dan seraya berkata: "Ya Tuhan Kami, tiadalah Engkau 
menciptakan ini dengan sia-sia Maha Suci Engkau, maka peliharalah Kami dari api neraka". (QS. 3: 191)

Kekuatan iman dan kesempurnaan Islam yang diraih dengan melakukan haji disinyalir oleh Allah melalui firman-Nya yang turun ketika Rasulullah SAW melaksanakan haji wada' (Haji Perpisahan) yakni: "Pada hari ini telah Ku-sempurnakan agama dan nikmat bagimu dan Ku-ridhai Islam jadi agama bagimu'(QS. 5: 3). ${ }^{9}$

\section{Haji Sebagai Aktualisasi Diri (Self Actualization)}

Abraham Maslow ${ }^{1}$ (tokoh Psikologi Humanistik ${ }^{1}$ yang dikenal dengan hierarki kebutuhan manusia ${ }^{1}$ ) menyatakan bahwa kebutuhan manusia yang paripurna adalah aktualisasi diri sesuai dengan potensinya sehingga menjadi manusias yang otentik. Arti aktualisasi diri ini hampir bersamaan dengan istilah-istilah yang dikemukakan tokoh-tokoh Psikologi Humanistik lainnya seperti Rogers dengan Fully Functioning Person (Kesempurnaan Fungsi Manusia), dan Jean Paul Sartre dengan proses meng-ada (to be being). Semua istilah ini mencoba mengembalikan manusia pada potensi yang sebenarnya (memanusiakan manusia) sehingga ia menjadi manusia sejati.

Haji sebagai penerapan 2 potensi manusia dapat dikategorikan bahwa ibadah ini sebagai aktualisasi diri dalam habl min Allah dan habl min an-naas.

$$
\begin{aligned}
& \text { ربنا ما خلقت هذا باطلا، سبحانك فقنا عذاب النار } \\
& \text { اليوم أكملت لكم دينكم وأتممت عليكم نعمتي ورضيت لكم الإسلام دينا.... }
\end{aligned}
$$

1 Seorang psikolog Amerika (1908 -1970) lahir di Brooklyn, New York. Ia memperoleh latihan profisionalnya pada universitas Wisconsin di mana ia memperoleh gelar Ph.D. tahun 1934. (Anshari: 347).

1 Humanistik menurut Herder menagndung di dalamnya "keramahtamahan", kepastian diri, seni hidup, pergaulan, suka bergaul, umumnya humanis sebagai lawan dari "kebinatangan".(Arnold: 260).

1 Sebelum mennggapai aktualisasi diri, Maslow memberikan prasyarat yang harus dipuaskan yakni 1. Kebutuhan fisiologis (makan, minum, seks dan bentuk-bentuk yang berkaitan dengan 
Di mana manusia mencoba meng-ada-kan (to be being) dirinya di hadapan Allah dengan memenuhi panggilan-Nya ke tanah suci karena ia (mungkin) telah meng-ada sebagai manusia di atas bumi. Dengan demikian ia akan mencapai otentitas dan kesempurnaan diri sebagai manusia (Fully Function Person).

Dengan melihat hal di atas penulis melihat berapa banyak muslim yang bertambah dekat dengan Rabb-nya pascaibadah haji dan betapa banyak pula yang malah kabur dan ngawur. Hal itu disebabkan kedua landasan utama belum terpatri dalam jiwa dan dirinya.

\section{Penutup}

Maha Suci Allah yang menciptakan segala sesuatu dengan berbagai hikmah demikian juga dengan haji. Haji merupakan proses menuju manusia sejati yang mampu memilih dan memilah kapan ia sebagai hamba dan kapan ia sebagai pemimpin.

Ya Allah, aku datang memenuhi pangilan-Mu

Dengan memohon magfirah dan hidayah-Mu

Hidupku dan matiku hanya untuk-Mu

Ampuni diriku sebagai hamba-Mu

Bimbing diriku sebagai khalifah-MU

Sehingga sempurna hidupku dengan ridha-Mu

\section{Waallahu 'alamu bis shawaab.}

kelangsungan hidup), 2.kebutuhan akan rasa aman, 3. Kebutuhan akan rasa memiliki dan cinta dan 4. Kebutuhan akan penghargaan, serta 5. Aktualisasi diri. (Schultz: 90). 


\section{DAFTAR BACAAN}

al-Quran dan Terjemahnya

Anshari, Hafi, Kamus Psikologi, Surabaya: Usaha Nasional, 1996

Departemen Agama, al-Quran dan Tafsirnya, jilid ke-1, 1983/1984

Goble, Frank.G., The Third Force, The Psychology of Abraham Maslow, diterjemahkan oleh A. Supratiknya "Mazhab Ketiga Psikologi Humanistik Maslow" Yogyakarta: Kanisius, 1987.

Hamka, Tafsir al-Azhar, Jakarta: Yayasan Nurul Islam, tt

Hijazy, Muhammad Mahmud, al-Tafsir al-Wadih, jilid ke I, Beirut: Dar al-Jiil, 1993

M.B. Arnold, Lexicon der Pedagogik II, Herder, Freiburg, Basel, Wien, 1970

Schultz, Duane, Psikologi Perkembangan, Yogyakarta: Kanisius, 2002 